\title{
Acid-Base Disturbances in Patients with Asthma: A Literature Review and Comments on Their Pathophysiology
}

\author{
Ioannis Vasileiadis ${ }^{1, *}$, Emmanouil Alevrakis ${ }^{2}$, Sevasti Ampelioti ${ }^{3}$, Dimitrios Vagionas ${ }^{1}$, \\ Nikoletta Rovina ${ }^{1}$ and Antonia Koutsoukou ${ }^{1}$ \\ 1 Intensive Care Unit, 1st Department of Respiratory Medicine, National and Kapodistrian University of \\ Athens, Sotiria Hospital, 11527 Athens, Greece; vagionasdimitrios@gmail.com (D.V.); \\ nikrovina@med.uoa.gr (N.R.); koutsoukou@yahoo.gr (A.K.) \\ 2 4th Department of Respiratory Medicine, Sotiria Hospital, 11527 Athens, Greece; m.alevrakis@gmail.com \\ 3 5th Department of Respiratory Medicine, Sotiria Hospital, 11527 Athens, Greece; sevi.ampelioti@gmail.com \\ * Correspondence: ioannisvmed@yahoo.gr or ivasileiadis@med.uoa.gr; Tel: +30-697-764-4866 or \\ +30-210-7763725; Fax: +30-210-778-1250
}

Received: 27 March 2019; Accepted: 23 April 2019; Published: 25 April 2019

\begin{abstract}
Asthma is a common illness throughout the world that affects the respiratory system function, i.e., a system whose operational adequacy determines the respiratory gases exchange. It is therefore expected that acute severe asthma will be associated with respiratory acid-base disorders. In addition, the resulting hypoxemia along with the circulatory compromise due to heart-lung interactions can reduce tissue oxygenation, with a particular impact on respiratory muscles that have increased energy needs due to the increased workload. Thus, anaerobic metabolism may ensue, leading to lactic acidosis. Additionally, chronic hypocapnia in asthma can cause a compensatory drop in plasma bicarbonate concentration, resulting in non-anion gap acidosis. Indeed, studies have shown that in acute severe asthma, metabolic acid-base disorders may occur, i.e., high anion gap or non-anion gap metabolic acidosis. This review briefly presents studies that have investigated acid-base disorders in asthma, with comments on their underlying pathophysiology.
\end{abstract}

Keywords: asthma; lactic acidosis; hyperchloremic acidosis; hypocapnia; hypercapnia

\section{Introduction}

Asthma is a common yet complex airway disease, characterized mainly by chronic airway inflammation and temporal variability in symptoms and expiratory airflow limitation. A complete analysis of the pathophysiology of the disease is beyond the scope of this paper, but a brief review of the main mechanisms involved in disease exacerbations is necessary to better grasp the acid-base derangements often encountered in these patients. Although asthma is increasingly being recognized as a heterogeneous disease with many different phenotypes, the mechanics of disease exacerbation seem to be common amongst patients. In acute asthma exacerbations, exposure to a precipitating factor leads to an exaggerated inflammatory response in the airways owing to an innate airway hyperresponsiveness in these patients. The immediate result of this inflammatory response is contraction of bronchial smooth muscles, bronchial edema, and mucus hypersecretion leading to mucus plugging. The consequent narrowing of airway diameter leads to increases in airway resistance and limitation of expiratory flow, and hence to air trapping and dynamic hyperinflation. As tidal breathing then starts taking place within the flat portion of the pressure-volume curve, the elastic work of breathing is dramatically increased. Hyperinflation essentially leads to the generation of an inspiratory threshold, which is reflected by the presence of positive end-expiratory pressure (auto-PEEP). This inspiratory threshold 
must be overcome by the inspiratory muscles during each breath in order for inspiratory flow to begin. Another deleterious factor is the disadvantageous positioning of respiratory muscle length-tension curves in these large lung volumes, necessitating the recruitment of accessory inspiratory and expiratory muscles, further contributing to respiratory muscle fatigue [1].

The aforementioned pathophysiological mechanisms eventually lead the deteriorating patient towards ventilatory failure. Nonetheless, acute respiratory failure is a far more common event in acute asthma. Indeed, hypoxemia is widely prevalent, with $\mathrm{PaO}_{2}$ levels of less than $60 \mathrm{mmHg}$ even in non-severe asthma [2] having being reported in several studies [3]. Even though this effect was attributed to ventilation/perfusion $\left(\mathrm{V}_{\mathrm{A}} / \mathrm{Q}\right)$ inequalities owing to regional differences in airflow, it was not until the advent of the multiple inert gas elimination technique that this phenomenon was adequately demonstrated [4].

The pathophysiological disorders in asthma result in various acid-base disturbances; these are summarized in Figure 1 and are briefly discussed below.

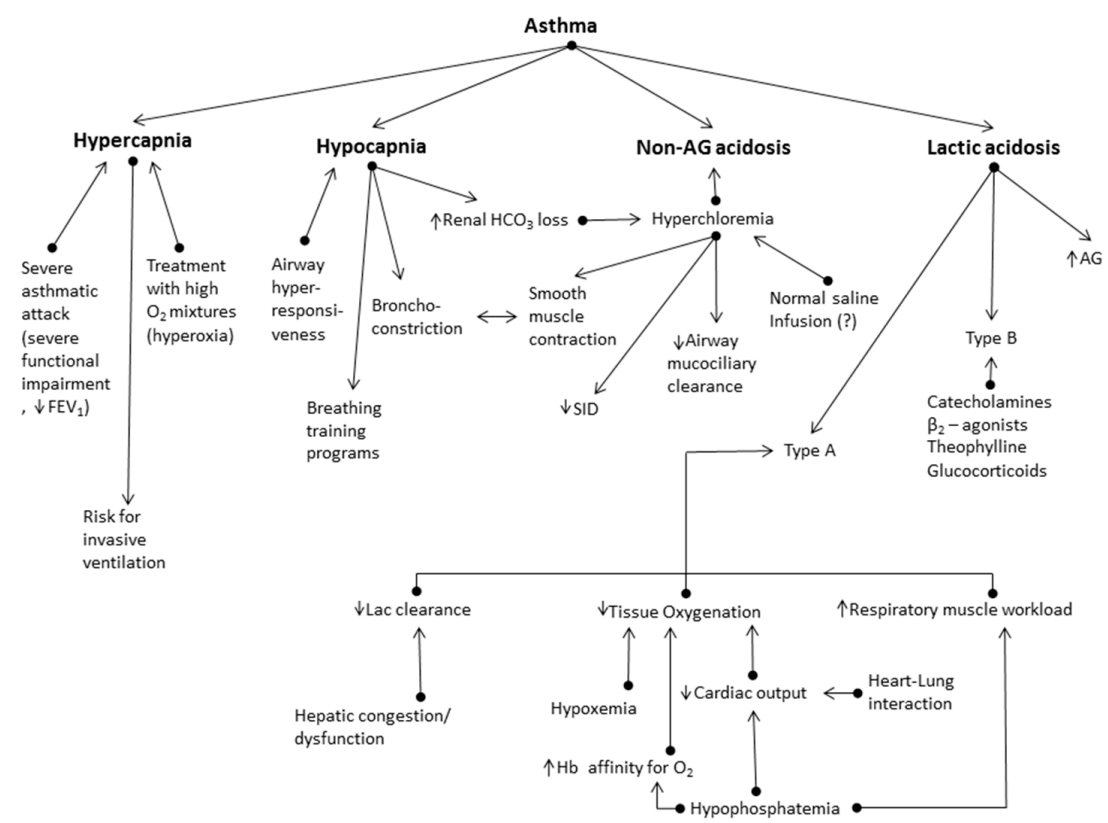

Figure 1. Acid-base disorders in asthma. $\mathrm{FEV}_{1}=$ forced expiratory volume in $1 \mathrm{~s} . \mathrm{AG}=$ anion-gap.

\section{Respiratory Alkalosis}

Acute asthmatic crisis is usually accompanied by hyperventilation and hypocapnia with respiratory alkalosis [3,5]. However, it seems that mild, asymptomatic asthma is also associated with hypocapnia. Studies that have demonstrated hypocapnia in asymptomatic asthmatics, as well as during asthmatic attacks, are presented in Table 1.

Table 1. Respiratory alkalosis.

\begin{tabular}{ccccc}
\hline Study & Study Design & Study Population & Methods & Significant Findings \\
\hline $\begin{array}{c}\text { Osborne C.A. et al., } \\
\text { 2000 [6] }\end{array}$ & Case-Control Study & $\begin{array}{c}23 \text { asymptomatic asthmatics, } \\
17 \text { healthy subjects }\end{array}$ & $\begin{array}{c}\text { Measured various stable } \\
\text { state parameters }\end{array}$ & $\begin{array}{c}\text { PaCO } \\
\text { asymptomatic asthmatics }\end{array}$ \\
\hline $\begin{array}{c}\text { Van den Elshout et al., } \\
\text { 1991 [7] }\end{array}$ & Case- Control Study & $\begin{array}{c}30 \text { asthmatics, } \\
17 \text { healthy subjects }\end{array}$ & $\begin{array}{c}\text { Induction of hypercapnia } \\
\text { and hypocapnia }\end{array}$ & $\begin{array}{c}\text { Hypocapnia induced } \\
\text { increases in airway resistance } \\
\text { in asthmatic patients }\end{array}$ \\
\hline $\begin{array}{c}\text { Raimondi et al., } \\
\text { 2013 [8] }\end{array}$ & Case series & $\begin{array}{c}314 \text { patients admitted } \\
\text { for ASA }\end{array}$ & $\begin{array}{c}\text { ABGs, electrolytes } \\
\text { and spirometry } \\
\text { results documented }\end{array}$ & $\begin{array}{c}\text { Hypocapnia was prominent } \\
\text { in less severe asthma } \\
\text { exacerbations }\end{array}$ \\
\hline
\end{tabular}

In a study, asymptomatic patients with asthma had significantly lower partial pressure of carbon dioxide $\left(\mathrm{PCO}_{2}\right)$ in arterial blood and end-tidal $\mathrm{PCO}_{2}\left(\mathrm{P}_{\mathrm{ET}} \mathrm{CO}_{2}\right)$ values compared to normal subjects, 
with no difference in the ventilatory pattern [6]. To note, there was no statistically significant difference in the other acid-base variables between asthma patients and healthy controls, i.e., the $\mathrm{pH}$ values were similar in both groups. Hypocapnia was attributed to airway hyperresponsiveness. In another study, similar results were found; normal subjects had higher $\mathrm{P}_{\mathrm{ET}} \mathrm{CO}_{2}$ at rest compared to asthmatic patients. This study evaluated the effect of hypocapnia and hypercapnia in patients with asthma and in healthy subjects. It was found that while the fall of $\mathrm{PCO}_{2}$ increased airway resistance in asthmatic patients, it did not significantly change the respiratory resistance in normal individuals [7]. It was suggested that hypocapnia is probably associated with the airway obstruction observed in asthmatics, thus having an important role in the pathophysiology of asthma. Low $\mathrm{PCO}_{2}$ has been demonstrated to increase airway smooth muscle tension in animal models, as well; the proposed mechanism by which hypocapnia affects smooth muscle contraction is the alteration of calcium uptake due to an increase in intracellular $\mathrm{pH}[9,10]$. Corroborating the above findings, it has further been shown that high $\mathrm{PCO}_{2}$ values cause bronchodilation and reduce airway resistance in both asthma patients and normal subjects $[7,11]$. As hypocapnia has been implicated in the pathophysiology of asthma, training techniques have been proposed to improve patients' respiratory pattern, reduce hyperventilation, and increase $\mathrm{PCO}_{2}$, in an attempt to reverse the bronchoconstrictive effect of hypocapnia. Breathing retraining has been used in the management of asthma. The Buteyko breathing technique, an innovative treatment approach for asthma, named after Professor Konstantin Buteyko, has been widely applied [12]. In a recent trial, breathing training programs improved disease-related quality of life in adult asthmatic patients [13].

\section{Respiratory Acidosis}

Respiratory acidosis is a very common acid base disturbance in acute severe asthma and is widely considered to be an ominous finding. Its early recognition and treatment is important and decisive for the final outcome, as it can lead to respiratory failure and arrest if prolonged. Studies relating hypercapnia during asthmatic attacks are presented in Table 2.

Table 2. Respiratory acidosis.

\begin{tabular}{|c|c|c|c|c|}
\hline Study & Study Design & Study Population & Methods & Significant Findings \\
\hline $\begin{array}{c}\text { Mountain et al., } \\
1988 \text { [14] }\end{array}$ & Retrospective & $\begin{array}{c}61 \text { patients with hypercapnic } \\
\text { ASA, } 168 \text { with } \\
\text { nonhypercapnic ASA }\end{array}$ & Various outcomes documented & $\begin{array}{c}\text { Hypercapnic patients had more } \\
\text { severe airway } \\
\text { obstruction, symptoms }\end{array}$ \\
\hline $\begin{array}{l}\text { Lee K.H. et al., } \\
1997 \text { [15] }\end{array}$ & Retrospective & $\begin{array}{c}48 \text { patients with } \\
49 \text { admissions to the ICU } \\
\text { due to ASA }\end{array}$ & Various outcomes documented & $\begin{array}{c}\text { Respiratory acidosis linked to } \\
\text { higher mortality }\end{array}$ \\
\hline $\begin{array}{l}\text { Raimondi et al., } \\
2013 \text { [8] }\end{array}$ & Case series & $\begin{array}{l}314 \text { patients admitted } \\
\text { for ASA }\end{array}$ & $\begin{array}{l}\text { ABGs, electrolytes and } \\
\text { spirometry results documented }\end{array}$ & $\begin{array}{c}\text { Inverse correlation between } \\
\mathrm{FEV}_{1} \text { and respiratory acidosis. } \\
\text { Inability to perform spirometry } \\
\text { linked to high } \mathrm{pCO}_{2}\end{array}$ \\
\hline $\begin{array}{l}\text { Cham et al., } \\
2002[16]\end{array}$ & $\begin{array}{l}\text { Prospective } \\
\text { observational }\end{array}$ & $\begin{array}{l}127 \text { patients with severe } \\
\text { exacerbation of asthma and } \\
\text { COPD in the ED }\end{array}$ & $\begin{array}{l}\text { Acute respiratory acidosis } \\
\text { documented and linked to } \\
\text { clinical presentation }\end{array}$ & $\begin{array}{l}\text { Drowsiness linked to sevenfold } \\
\text { likelihood of respiratory } \\
\text { acidosis. Flushing and } \\
\text { intercostal retractions good } \\
\text { predictors of } \\
\text { respiratory acidosis }\end{array}$ \\
\hline
\end{tabular}

Abbreviations used: $\mathrm{ICU}=$ intensive care unit, $\mathrm{COPD}=$ chronic obstructive pulmonary disease, $\mathrm{pCO}_{2}=$ partial carbon dioxide pressure, $\mathrm{ED}=$ emergency department.

In asthmatic patients, hypercapnia and respiratory acidosis occur in clinical exacerbations characterized by severe airway obstruction [14]. Simpson et al., in one of the earliest published studies, noted that hypoxemia and respiratory acidosis are common in children with acute severe asthma, as in 10 out of the 24 acute attacks that were studied $\mathrm{CO}_{2}$ retention was observed, while three patients developed carbon dioxide narcosis [17]. On the other hand, Weng et al. found that the degree of hypoxemia correlated with the degree of airway obstruction, but neither $\mathrm{PaCO}_{2}$ nor $\mathrm{pH}$ did. This study reported 177 events in 139 asthmatic children, both symptomatic and asymptomatic. Respiratory acidosis or mixed acidosis was present in severely dyspneic patients [18]. Lee et al. noted that $\mathrm{PaCO}_{2}$ was significantly higher and the arterial blood $\mathrm{pH}$ lower in asthmatics who died, and delays 
in providing mechanical ventilation led to worse outcomes [15]. Several studies have attempted to find clinical signs that could be correlated to the presence of respiratory acidosis. Cham et al. tried to find clinical predictors for acute respiratory acidosis in 141 episodes in patients with either asthma or chronic obstructive pulmonary disease (COPD). A total of 41 patients had hypercapnia $(32.3 \%)$, and acidosis was present in $27(65.9 \%)$. The frequency of acute respiratory acidosis was 0.39 in COPD and 0.10 in asthma. Drowsiness, flushing, and intercostal retractions were strong predictors for acute respiratory acidosis [16]. It has also been reported that the absence of pulsus paradoxus makes the presence of hypercapnia unlikely, although it is noted that clinical signs and symptoms during acute severe asthma often are not correlated with the severity of the functional impairment [19]. Raimondi et al. performed a case series study exploring acid-base patterns in patients admitted for acute severe asthma, in correlation with forced expiratory volume in $1 \mathrm{~s}\left(\mathrm{FEV}_{1}\right)$ values [8]. Airway obstruction severity did not seem to correlate significantly with $\mathrm{PaO}_{2}$ values, a finding also reported in several other studies in the past $[18,20,21]$ and thought to be due to $V_{A} / Q$ mismatch not being connected to air flow rates; moreover, treatment with $\beta$-agonists may lead to further widening of $\mathrm{V}_{\mathrm{A}} / \mathrm{Q}$ mismatch. A statistically significant reverse correlation was demonstrated between $\mathrm{FEV}_{1}$ and $\mathrm{PaCO}_{2}$ levels. Inability to complete spirometry was shown to be accompanied with a significantly higher frequency of respiratory acidosis, with some patients being deemed unable to undergo a spirometry maneuver by the attending physician. Less severe cases of acute asthma presented mostly with respiratory alkalosis.

Hypercapnia in asthma, in addition to the severity of the disease, is also associated with the therapeutic administration of oxygen. Thus, in patients with severe asthma exacerbation, significant increase $(\geq 4 \mathrm{mmHg})$ in transcutaneous $\mathrm{PCO}_{2}\left(\mathrm{PtCO}_{2}\right)$ was observed in a higher proportion in those receiving high oxygen mixtures $(>8 \mathrm{~L} / \mathrm{min}$ ), compared to those who received titrated oxygen (to achieve oxygen saturation of 93-95\%) [22]. Hypercapnia induced by hyperoxia has been known for quite some time, and has been mainly studied in patients with COPD. For the pathophysiological interpretation of the mechanism involved, the simplistic view of Campbell (1960) had prevailed, who assumed that in chronic COPD patients with hypercapnia, respiratory control is based only on hypoxic drive as their hypercapnic respiratory drive is blunted [23]. Subsequent studies, mainly in patients with COPD, did not confirm this hypothesis. It was found that oxygen-induced hypercapnia does not indicate a deficiency/impairment of the respiratory control system for $\mathrm{CO}_{2}$ homeostasis and is not correlated with changes in ventilation. Instead, the reduction of $\mathrm{V}_{\mathrm{A}} / \mathrm{Q}$ matching was proposed as the cause, due to the release of hypoxic pulmonary arterial vasoconstriction, with a consequent increase in functional dead space ventilation [24-28]. However, in another study in COPD patients, oxygen-induced hypercapnia was characterized by reduction in ventilation; the increased dead-space ventilation in the group of patients where $\mathrm{PCO}_{2}$ increased more than $3 \mathrm{mmHg}$ (retainers) was attributed to bronchodilation due to the higher $\mathrm{CO}_{2}$ tension [29]. Another mechanism implicates the Haldane effect, in which oxygen displaces the $\mathrm{CO}_{2}$ dissociation curve to the right, increasing $\mathrm{PaCO}_{2}$, which cannot be normalized as patients with severe COPD are unable to increase ventilation $[25,30]$.

\section{Metabolic acidosis}

Non-anion gap (non-AG) metabolic acidosis as well as increased AG acidosis may occur in asthma (Table 3).

Table 3. Metabolic acidosis.

\begin{tabular}{ccccc}
\hline Study & Study Design & Study Population & Methods & Significant Findings \\
\hline $\begin{array}{c}\text { Mountain, R.D. et al., } \\
\text { 1990 [31] }\end{array}$ & Retrospective & $\begin{array}{c}\text { 229 acute asthma } \\
\text { episodes in 170 patients } \\
\text { (Hospital Admissions) }\end{array}$ & $\begin{array}{c}\text { Clinical features and arterial } \\
\text { blood gases examined }\end{array}$ & $\begin{array}{c}\text { Simple or mixed metabolic } \\
\text { acidosis in 28\% of the episodes. }\end{array}$ \\
$\begin{array}{c}\text { Rashid, A.O. et al., } \\
\text { 2008 [32] }\end{array}$ & Retrospective & $\begin{array}{c}109 \text { patients hospitalized } \\
\text { for asthma exacerbations }\end{array}$ & $\begin{array}{c}\text { Acid-base, electrolyte status } \\
\text { and outcomes }\end{array}$ & $\begin{array}{c}10.1 \% \text { AG acidosis, 29.4\% NAG } \\
\text { acidosis. NAG acidosis patients } \\
\text { had significantly higher } \\
\text { intubation rates }\end{array}$ \\
\hline
\end{tabular}


Table 3. Cont.

\begin{tabular}{|c|c|c|c|c|}
\hline Study & Study Design & Study Population & Methods & Significant Findings \\
\hline $\begin{array}{l}\text { Meert, K.L. et al., } \\
2012[34]\end{array}$ & $\begin{array}{l}\text { Prospective } \\
\text { observational }\end{array}$ & $\begin{array}{l}105 \text { children with ASA } \\
\text { admitted to a PICU }\end{array}$ & $\begin{array}{l}\text { Blood lactate measurements } \\
\text { followed by lactate/pyruvate } \\
\text { ration measurements }\end{array}$ & $\begin{array}{c}\text { Primarily type B lactic acidosis } \\
\text { (associated with normal oxygen } \\
\text { delivery). Presumed to be due to } \\
\beta \text {-adrenergic stimulation }\end{array}$ \\
\hline $\begin{array}{l}\text { Raimondi et al., } \\
2013[8]\end{array}$ & Case Series & $\begin{array}{l}314 \text { patients admitted } \\
\text { for ASA }\end{array}$ & $\begin{array}{l}\text { ABGs, electrolytes and } \\
\text { spirometry results documented }\end{array}$ & $\begin{array}{l}\text { Most cases of metabolic acidosis } \\
\text { attributed to chronic hypocapnia. } \\
\text { Hyperlactatemia attributed } \\
\text { mostly to adrenergic stimulation }\end{array}$ \\
\hline
\end{tabular}

Abbreviations used: AG = anion-gap, NAG = non-anion gap, PEF = peak expiratory flow, PICU: pediatric intensive care unit, $\mathrm{PaCO}_{2}=$ partial carbon dioxide tension.

\subsection{Non-Anion Gap Metabolic Acidosis}

Although metabolic acidosis in asthma is often considered to be secondary to hyperlactatemia, non-anion gap (non-AG) metabolic acidosis has also been reported. The presence (and absence thereof) of non-AG in patients with acute asthma has been a subject of debate in medical literature, with many studies $[3,4]$ reporting no such findings, and others $[35,36]$ documenting simple or mixed metabolic acidosis in as many as $38 \%$ of the study population. Mountain et al. noted that metabolic acidosis in acute asthma was more likely to occur in male patients and in patients with greater airflow obstruction and lower $\mathrm{FEV}_{1}$ [31]. Rashid et al. studied the clinical outcome in 109 adult patients hospitalized for asthma exacerbations. These patients were divided in three groups: group I included those patients who did not present with metabolic acidosis, group II those with AG metabolic acidosis, and group III those with non-AG metabolic acidosis. Out of these, 32 (29.4\%) developed non-AG metabolic acidosis, while metabolic acidosis with elevated anion gap occurred in 11 patients $(10.1 \%)$ [32]. The group of patients with non-AG metabolic acidosis had significantly higher chloride anion $\left(\mathrm{Cl}^{-}\right)$concentrations, with a tendency to hyperchloremia, while sodium $\left(\mathrm{Na}^{+}\right)$and potassium $\left(\mathrm{K}^{+}\right)$concentrations were not different compared to patients without acidosis or with elevated AG acidosis. The patients with non-AG acidosis were also at increased risk of respiratory failure and need for invasive, mechanical ventilation. Another study evaluated the acid-base status in 22 patients with acute severe asthma [36]. Ten patients had metabolic acidosis, defined by a base deficit $>2 \mathrm{mEq} / \mathrm{L}$. None of these patients had an elevated AG. The most likely explanation for the observed metabolic acidosis in these patients, as in the previous study, was the renal loss of bicarbonates $\left(\mathrm{HCO}_{3}{ }^{-}\right)$due to renal compensation for preexistent, sustained hypocapnia. The $\mathrm{HCO}_{3}{ }^{-}$levels were low-normal or decreased in these patients, while the $\mathrm{pH}$ values ranged from alkaline to moderately acidotic. It appears that non-AG acidosis is a frequent acid-base disorder in asthmatic exacerbations, due to the excretion of $\mathrm{HCO}_{3}{ }^{-}$, in response to chronic, sustained hypocapnia. Hypocapnia immediately shifts the dissociation reaction of $\mathrm{H}_{2} \mathrm{CO}_{3}$ to the left

$$
\mathrm{CO}_{2}+\mathrm{H}_{2} \mathrm{O} \leftrightarrow \mathrm{H}_{2} \mathrm{CO}_{3} \leftrightarrow \mathrm{H}^{+}+\mathrm{HCO}_{3}^{-}
$$

reducing $\mathrm{H}^{+}$and $\mathrm{HCO}_{3}{ }^{-}$concentrations and increasing $\mathrm{pH}$. In the short term, the decrease in $\mathrm{PaCO}_{2}$ alkalinizes the extracellular fluid, to the extent predicted by the Henderson-Hasselbalch equation. Persistent hypocapnia causes a further decrease in $\mathrm{HCO}_{3}{ }^{-}$concentration, due to suppression of renal acid secretion/increase of $\mathrm{HCO}_{3}{ }^{-}$excretion [37,38]. By definition, the primary metabolic acidosis of this type, i.e., with non-elevated AG, is accompanied by an increase in the concentration of $\mathrm{Cl}^{-}$, i.e., hyperchloremic acidosis [39]. Hyperchloremic, non-AG acidosis, secondary to chronic hypocapnia, was also noted in the study of Rashid et al. [32], in asthmatic patients. However, in an earlier animal study it was found that, during compensation for hypocapnia, the reduction in renal proton excretion was associated with increased $\mathrm{Na}^{+}$excretion and not with $\mathrm{Cl}^{-}$retention and hyperchloremia [40]. Furthermore, in another study, chronic hypocapnia was found to suppress renal acid secretion while 
inducing renal $\mathrm{K}^{+}$wasting [41]. Interestingly, in a recent study [42], ascent to high altitude elicited a hypoxic ventilatory response in normal adults, resulting in increased ventilation and decreased $\mathrm{PaCO}_{2}$; hypocapnia was accompanied by strong ion difference (SID) reduction, signaling metabolic acidosis according to Stewart's view [43]. Concerning the non-AG metabolic acidosis in patients with asthma, as a compensatory response to chronic hypocapnia, we should comment on the following issues:

1. Insofar as chronic hypocapnia in these patients is accompanied by hyperchloremia, the role of $\mathrm{Cl}^{-}$channels in vascular and non-vascular smooth muscle contraction, as in the human airways, must be stressed, e.g., an alteration of $\mathrm{Cl}^{-}$concentration changes the myogenic tone in the blood vessels [44,45]. Additionally, $\mathrm{Cl}^{-}$channels in epithelial cells may affect mucus hydration on the airway surfaces [46]. Overall, $\mathrm{Cl}^{-}$may have a critical role in asthma pathophysiology.

2. In conditions like asthma exacerbations, where an acute acid-base disorder complicates a chronic respiratory disorder, such as chronic hypocapnia in asthmatics, the use of base excess (or base deficit) method [47] to assess the severity of metabolic acidosis can lead to 'erroneous assessment' of the patient's acid-base status, lacking any clinical relevance. Thus, in the study of Okrent et al. [36], in patients with acute severe asthma, metabolic acidosis was diagnosed by the increase of base deficit $>2 \mathrm{mEq} / \mathrm{L}$. In this study, authors supported that this indicated a true loss of the body's alkaline reserve. Nevertheless, one of the patients with the more severe metabolic acidosis, diagnosed with the base excess criterion $(-4.9 \mathrm{mEq} / \mathrm{L})$, had hypocapnia $\left(\mathrm{PCO}_{2}=27 \mathrm{mmHg}\right), \mathrm{pH}$ higher than the mean physiological value (7.43), and $\mathrm{HCO}_{3}{ }^{-}$concentration lower than the normal value $(19 \mathrm{mEq} / \mathrm{L})$, for which, however, no treatment is indicated, and which actually corresponds to the expected metabolic compensation for a chronic respiratory alkalosis (the expected $\mathrm{HCO}_{3}{ }^{-}$concentration reduction $\left(\Delta\left(\mathrm{HCO}_{3}{ }^{-}\right)\right)$equals $0.4 \times \Delta \mathrm{PCO}_{2}$, i.e., $\left.\left(\mathrm{HCO}_{3}{ }^{-}\right)=18.8 \mathrm{mEq} / \mathrm{L}\right)$ [37]. Thus, the physiologic compensation for an uncomplicated acid-base disturbance has been viewed as a serious metabolic acidosis superimposed on the chronic respiratory disorder. Overall, caution is needed in assessing the metabolic component of these acid-base disorders by utilizing the base excess values; diagnostic errors and therapeutic ill-practices may occur when they are not considered alongside the required clinical information. Criticism on the subject has long been made by Schwartz and Relman [48], which even took the form of a 'transatlantic debate' with arguments from both sides [49].

3. Finally, regarding the increased clinical risk demonstrated in asthmatics with non-AG acidosis (accompanied by hyperchloremia) [32], it should be noted that there are several studies suggesting that hyperchloremia per se is associated with poor outcome in hospitalized and critically ill patients [50-52]. Hyperchloremia induced by intravenous administration of crystalloid solutions with high $\mathrm{Cl}^{-}$concentration is not to be overlooked [53,54], although there is no study investigating this issue exclusively in patients with acute severe asthma. In addition, hypocapnia, besides the acid-base balance, can have serious effects on the organs and systems in the body, and can adversely affect outcome in the critically ill [55].

\subsection{Lactic Acidosis}

Hyperlactatemia is a very common finding in patients with acute severe asthma. Lactic acidosis has two types: type $\mathrm{A}$, which is associated with impaired oxygen delivery; and type $\mathrm{B}$, where the oxygen delivery is normal but cellular function is impaired. The exact cause of lactic acidosis in these patients remains elusive, and several possible mechanisms have been proposed over the years. Acute severe asthma is characterized by hypoxemia $[3,56]$ and may be accompanied by functional cardiac disorders (heart-lung interaction); increased right ventricular (RV) afterload during acute severe asthma, with increased impedance to RV ejection, and reduction of left ventricular (LV) preload and LV compliance due to leftward septal shift may reduce cardiac output $[57,58]$. Thus, lactate increase may result from severe hypoperfusion and decrease in oxygen supply to the tissues. In addition, respiratory muscle fatigue, due to increased respiratory muscle work load, can also increase lactate levels [59,60], especially under hypoxic conditions along with compromised tissue perfusion. In patients with acute severe asthma, a negative correlation between the peak lactate levels and the phosphate levels on 
admission was found [33]. In this study, hypophosphatemia preceded the increase in lactate levels in most patients. Hypophosphatemia may complicate treatment with bronchodilators in acute severe asthma patients [61]. Low phosphate levels in the blood may lead to reduced ATP synthesis in the muscles, accounting for muscle weakness and respiratory and heart failure [62]. Additionally, hypophosphatemia is known to impair the contractile properties of the diaphragm [63] and increase the hemoglobin affinity for oxygen due to a decrease in 2,3-diphosphoglycerate (2,3-DPG) [64], compromising tissue oxygenation. In a state of low cardiac output, hepatic perfusion decreases; also, the RV function disorder can increase the right heart filling pressures and lead to hepatic congestion [65-67]. Thus, hepatic dysfunction during acute severe asthma may result in impaired lactate clearance and hyperlactatemia $[68,69]$. An increase in lactate levels can also be observed during clinical improvement after bronchodilator treatment. It has been suggested that reperfusion of the previously ischemic organs, e.g., respiratory muscles, can lead to lactate release [70,71]. That is, the increase in lactate intracellular levels during the period of ischemia and anaerobic respiration may not be reflected in the lactate circulating levels in the serum. Serum lactate concentration can be increased after restoring tissue perfusion. Increased catecholamines in plasma may increase metabolic rate and lactate production without coexisting cell hypoxia. Increased levels of catecholamines in the blood have been found in patients with asthma, especially norepinephrine [72]. Additionally, catecholamines are used therapeutically during acute severe asthma, to promote bronchodilatation [73] and/or hemodynamic support. However, catecholamines have marked metabolic effects and may cause hyperlactatemia [74]. Treatment with bronchodilators has also been implicated in the lactate increase, i.e., the use of $\beta_{2}$-adrenergic agonists, such as salbutamol [75]. In animals, $\beta_{2}$-adrenoreceptor stimulation after salbutamol administration induced a significant increase in plasma lactate concentration; lactate increase was inhibited by clonidine ( $\alpha_{2}$-adrenoreceptor agonist), a drug with opposite effects on the system of adenylate cyclase [76]. Stimulation of $\beta_{2}$-adrenergic receptors increases glycogenolysis in the liver and muscle as well as lipolysis, through the increase of intracellular cAMP [77]. Free fatty acids liberated during lipolysis inhibit the oxidation of pyruvate by pyruvate dehydrogenase and may further increase lactate production [78]. Finally, theophylline and glucocorticoids may have a role in the increased lactate production during acute severe asthma. Theophylline is a non-selective 5 -phosphodiesterase inhibitor and potentiates the activity of $\beta$-adrenergic agents by increasing the intracellular concentration of cAMP [79-81]. Glucocorticoids are also known to increase the $\beta$-receptor's sensitivity to $\beta$-adrenergic agonists [82]. Thus, when treating severe asthma attack, despite improvement in bronchospasm, a patient may hyperventilate and look more dyspneic; this may be a compensatory mechanism for lactic acidosis induced by therapy, to maintain $\mathrm{pH}$ within normal limits, and should not be seen as a worsening of airway obstruction [83]. In order to distinguish the type of lactic acidosis (A and B), the ratio of the concentration of lactate to the concentration of pyruvate in the blood can be used. Under aerobic conditions, this ratio is normally low, whereas under anaerobic conditions, due to the inability of cells to further metabolize pyruvate in mitochondria, this ratio increases to levels $>25: 1[84,85]$. Thus, in a study concerning children with asthma, lactic acidosis was found to be predominantly of type B, with normal oxygen supply to the tissues, and was attributed to $\beta$-adrenergic stimulation [34].

\section{Conclusions}

Various acid-base disorders, of complex etiology, have been observed in asthma. Airway hyperresponsiveness leads to hyperventilation and chronic hypocapnia with a consequent increase in renal bicarbonate loss. This results in hyperchloremic acidosis, which becomes more clinically evident-with a clear effect on blood acidity-during severe asthma attacks, in case $\mathrm{PCO}_{2}$ normalizes or increases. Hypocapnia, and possibly hyperchloremia, may be related to the pathogenicity of the disease. Hypercapnia characterizes severe asthma attacks, with imminent risk for intubation and mechanical ventilation. Hypercapnia has been attributed to both the severity of the functional respiratory disorder and treatment with high oxygen mixtures (hyperoxia induced). Finally, increased AG metabolic 
acidosis has also been observed in asthma, i.e., lactic acidosis. Its etiology includes: a. disturbance of tissue oxygenation, e.g., by cardiac output reduction and hypoxemia or increased oxygen demands of respiratory muscles due to increased workload, $\mathbf{b}$. reduced lactate clearance due to liver congestion and dysfunction, and c. treatment effect, e.g., $\beta$-agonists, on cellular metabolism, resulting in increased lactate production. The thorough and careful evaluation of acid-base disorders in asthma will serve the differential diagnostic approach concerning the underlying pathogenetic disorder and its treatment.

Author Contributions: Conceptualization, I.V.; Investigation, I.V., E.A., and S.A.; Writing-Original Draft Preparation, I.V., E.A., S.A., and N.R.; Review and Editing, D.V., I.V., and A.K.; Supervision, I.V., N.R., and A.K.; Funding Acquisition, N.R.

Acknowledgments: In this section you can acknowledge any support given which is not covered by the author contribution or funding sections. This may include administrative and technical support, or donations in kind (e.g., materials used for experiments).

Conflicts of Interest: The authors declare no conflict of interest.

\section{References}

1. McFadden, E. Acute Severe Asthma. Am. J. Respir. Crit. Care Med. 2003, 168, 740-759. [CrossRef]

2. Tai, E.; Read, J. Blood-gas tensions in bronchial asthma. Lancet 1967, 1, 644-646. [CrossRef]

3. McFadden, E.R., Jr.; Lyons, H.A. Arterial blood gas tensions in asthma. N. Eng. J. Med. 1968, 278, 1027-1032. [CrossRef] [PubMed]

4. Rodriguez-Roisin, R.; Roca, J. Contributions of multiple inert gas elimination technique to pulmonary medicine. 3. Bronchial asthma. Thorax 1994, 49, 1027-1033. [CrossRef]

5. Rodriguez-Roisin, R. Gas exchange abnormalities in asthma. Lung 1990, 168, 599-605. [CrossRef]

6. Osborne, C.A.; O'Connor, B.J.; Lewis, A.; Kanabar, V.; Gardner, W.N. Hyperventilation and asymptomatic chronic asthma. Thorax 2000, 55, 1016-1022. [CrossRef]

7. Van den Elshout, F.J.; van Herwaarden, C.L.; Folgering, H.T. Effects of hypercapnia and hypocapnia on respiratory resistance in normal and asthmatic subjects. Thorax 1991, 46, 28-32. [CrossRef] [PubMed]

8. Raimondi, G.A.; Gonzalez, S.; Zaltsman, J.; Menga, G.; Adrogué, H.J. Acid-base patterns in acute severe asthma. J. Asthma 2013, 50, 1062-1068. [CrossRef] [PubMed]

9. Twort, C.H.; Cameron, I.R. Effects of $\mathrm{PCO}_{2}, \mathrm{pH}$ and extracellular calcium on contraction of airway smooth muscle from rats. Respir. Physiol. 1986, 66, 259-267. [CrossRef]

10. Lindeman, K.S.; Croxton, T.L.; Lande, B.; Hirshman, C.A. Hypocapnia-induced contraction of porcine airway smooth muscle. Eur. Respir. J. 1998, 12, 1046-1052. [CrossRef] [PubMed]

11. D'Angelo, E.; Calderini, I.S.; Tavola, M. The effects of $\mathrm{CO}_{2}$ on respiratory mechanics in anesthetized paralyzed humans. Anesthesiology 2001, 94, 604-610. [CrossRef] [PubMed]

12. Bruton, A.; Lewith, G.T. The Buteyko breathing technique for asthma: A review. Complement. Ther. Med. 2005, 13, 41-46. [CrossRef]

13. Bruton, A.; Lee, A.; Yardley, L.; Raftery, J.; Arden-Close, E.; Kirby, S.; Zhu, S.; Thiruvothiyur, M.; Webley, F.; Taylor, L.; et al. Physiotherapy breathing retraining for asthma: A randomised controlled trial. Lancet Respir. Med. 2018, 6, 19-28. [CrossRef]

14. Mountain, R.D.; Sahn, S.A. Clinical features and outcome in patients with acute asthma presenting with hypercapnia. Am. Rev. Respir. Dis. 1988, 138, 535-539. [CrossRef] [PubMed]

15. Lee, K.H.; Tan, W.C.; Lim, T.K. Severe asthma. Singap. Med. J. 1997, 38, 238-240, 243.

16. Cham, G.W.; Tan, W.P.; Earnest, A.; Soh, C.H. Clinical predictors of acute respiratory acidosis during exacerbation of asthma and chronic obstructive pulmonary disease. Eur. J. Emerg. Med. 2002, 9, $225-232$. [CrossRef] [PubMed]

17. Simpson, H.; Forfar, J.O.; Grubb, D.J. Arterial blood gas tensions and ph in acute asthma in childhood. Br. Med. J. 1968, 3, 460-464. [CrossRef] [PubMed]

18. Weng, T.R.; Langer, H.M.; Featherby, E.A.; Levison, H. Arterial blood gas tensions and acid-base balance in symptomatic and asymptomatic asthma in childhood. Am. Rev. Respir. Dis. 1970, 101, 274-282. 
19. Rosenzweig, J.R.C.; Edwards, L.; Lincourt, W.; Dorinsky, P.; ZuWallack, R.L. The relationship between health-related quality of life, lung function and daily symptoms in patients with persistent asthma. Respir. Med. 2004, 98, 1157-1165. [CrossRef]

20. Waddell, J.A.; Emerson, P.A.; Gunstone, R.F. Hypoxia in bronchial asthma. Br. Med. J. 1967, 2, $402-404$. [CrossRef]

21. Miyamoto, T.; Mizuno, K.; Furuya, K. Arterial blood gases in bronchial asthma. J. Allergy 1970, 45, $248-254$. [CrossRef]

22. Perrin, K.; Wijesinghe, M.; Healy, B.; Wadsworth, K.; Bowditch, R.; Bibby, S.; Baker, T.; Weatherall, M.; Beasley, R. Randomised controlled trial of high concentration versus titrated oxygen therapy in severe exacerbations of asthma. Thorax 2011, 66, 937-941. [CrossRef]

23. Tobin, M.J. Principles and Practice of Mechanical Ventilation, 3rd ed.; McGraw Hill Professional: New York, NY, USA, 2012; p. 87.

24. Aubier, M.; Murciano, D.; Fournier, M.; Milic-Emili, J.; Pariente, R.; Derenne, J.P. Central respiratory drive in acute respiratory failure of patients with chronic obstructive pulmonary disease. Am. Rev. Respir. Dis. 1980, 122, 191-199. [CrossRef]

25. Aubier, M.; Murciano, D.; Milic-Emili, J.; Touaty, E.; Daghfous, J.; Pariente, R.; Derenne, J.P. Effects of the administration of $\mathrm{O}_{2}$ on ventilation and blood gases in patients with chronic obstructive pulmonary disease during acute respiratory failure. Am. Rev. Respir. Dis. 1980, 122, 747-754. [CrossRef]

26. Sassoon, C.S.; Hassell, K.T.; Mahutte, C.K. Hyperoxic-induced hypercapnia in stable chronic obstructive pulmonary disease. Am. Rev. Respir. Dis. 1987, 135, 907-911. [CrossRef]

27. Dick, C.R.; Liu, Z.; Sassoon, C.S.; Berry, R.B.; Mahutte, C.K. $\mathrm{O}_{2}$-induced change in ventilation and ventilatory drive in COPD. Am. J. Respir. Crit. Care Med. 1997, 155, 609-614. [CrossRef] [PubMed]

28. Abdo, W.F.; Heunks, L.M. Oxygen-induced hypercapnia in COPD: Myths and facts. Crit. Care 2012, 16, 323. [CrossRef] [PubMed]

29. Robinson, T.D.; Freiberg, D.B.; Regnis, J.A.; Young, I.H. The role of hypoventilation and ventilation-perfusion redistribution in oxygen-induced hypercapnia during acute exacerbations of chronic obstructive pulmonary disease. Am. J. Respir. Crit. Care Med. 2000, 161, 1524-1529. [CrossRef]

30. Luft, U.C.; Mostyn, E.M.; Loeppky, J.A.; Venters, M.D. Contribution of the Haldane effect to the rise of arterial Pco2 in hypoxic patients breathing oxygen. Crit. Care Med. 1981, 9, 32-37. [CrossRef]

31. Mountain, R.D.; Heffner, J.E.; Brackett, N.C.; Sahn, S.A. Acid-base disturbances in acute asthma. Chest 1990, 98, 651-655. [CrossRef] [PubMed]

32. Rashid, A.O.; Azam, H.M.; DeBari, V.A.; Blamoun, A.I.; Moammar, M.Q.; Khan, M.A. Non-anion gap acidosis in asthma: Clinical and laboratory features and outcomes for hospitalized patients. Ann. Clin. Lab. Sci. 2008, 38, 228-234.

33. Rabbat, A.; Laaban, J.P.; Boussairi, A.; Rochemaure, J. Hyperlactatemia during acute severe asthma. Intensive Care Med. 1998, 24, 304-312. [CrossRef] [PubMed]

34. Meert, K.L.; McCaulley, L.; Sarnaik, A.P. Mechanism of lactic acidosis in children with acute severe asthma. Pediatr. Crit. Care Med. 2012, 13, 28-31. [CrossRef] [PubMed]

35. Roncoroni, A.; Adrogué, H.; De Obrutsky, C.W.; Marchisio, M.L.; Herrera, M. Metabolic acidosis in status asthmaticus. Respiration 1976, 33, 85-94. [CrossRef]

36. Okrent, D.G.; Tessler, S.; Twersky, R.A.; Tashkin, D.P. Metabolic acidosis not due to lactic acidosis in patients with severe acute asthma. Crit. Care Med. 1987, 15, 1098-1101. [CrossRef]

37. Adrogué, H.J.; Madias, N.E. Secondary responses to altered acid-base status: The rules of engagement. J. Am. Soc. Nephrol. 2010, 21, 920-923. [CrossRef]

38. Madias, N.E.; Adrogué, H.J. Cross-talk between two organs: How the kidney responds to disruption of acid-base balance by the lung. Nephron Physiol. 2003, 93, 61-66. [CrossRef]

39. Kraut, J.A.; Madias, N.E. Differential diagnosis of non-gap metabolic acidosis: Value of a systematic approach. Clin. J. Am. Soc. Nephrol. 2012, 7, 671-679. [CrossRef]

40. Gennari, F.J.; Goldstein, M.B.; Schwartz, W.B. The nature of the renal adaptation to chronic hypocapnia. J. Clin. Investig. 1972, 51, 1722-1730. [CrossRef]

41. Krapf, R.; Beeler, I.; Hertner, D.; Hulter, H.N. Chronic respiratory alkalosis. The effect of sustained hyperventilation on renal regulation of acid-base equilibrium. N. Engl. J. Med. 1991, 324, 1394-1401. [CrossRef] 
42. Zouboules, S.M.; Lafave, H.C.; O’Halloran, K.D.; Brutsaert, T.D.; Nysten, H.E.; Nysten, C.E.; Steinback, C.D.; Sherpa, M.T.; Day, T.A. Renal reactivity: Acid-base compensation during incremental ascent to high altitude. J. Physiol. 2018, 596, 6191-6203. [CrossRef] [PubMed]

43. Stewart, P.A. Independent and dependent variables of acid-base control. Respir. Physiol. 1978, 33, 9-26. [CrossRef]

44. Kitamura, K.; Yamazaki, J. Chloride channels and their functional roles in smooth muscle tone in the vasculature. Jpn. J. Pharmacol. 2001, 85, 351-357. [CrossRef] [PubMed]

45. Bulley, S.; Jaggar, J.H. $\mathrm{Cl}^{-}$channels in smooth muscle cells. Pflugers Arch. 2014, 466, 861-872. [CrossRef] [PubMed]

46. Wang, W.; Ji, H.L. Epithelial sodium and chloride channels and asthma. Chin. Med. J. (Engl.) 2015, 128, 2242-2249. [CrossRef] [PubMed]

47. Berend, K. Diagnostic use of base excess in acid-base disorders. N. Engl. J. Med. 2018, 378, 1419-1428. [CrossRef] [PubMed]

48. Schwartz, W.B.; Relman, A.S. A critique of the parameters used in the evaluation of acid-base disorders. "Whole-blood buffer base" and "standard bicarbonate" compared with blood $\mathrm{pH}$ and plasma bicarbonate concentration. N. Engl. J. Med. 1963, 268, 1382-1388. [CrossRef]

49. Severinghaus, J.W. Siggaard-andersen and the "great trans-atlantic acid-base debate". Scand. J. Clin. Lab. Investig. Suppl. 1993, 214, 99-104.

50. Neyra, J.A.; Canepa-Escaro, F.; Li, X.; Manllo, J.; Adams-Huet, B.; Yee, J.; Yessayan, L.; Acute Kidney Injury in Critical Illness Study Group. Association of hyperchloremia with hospital mortality in critically Ill septic patients. Crit. Care Med. 2015, 43, 1938-1944. [CrossRef]

51. Thongprayoon, C.; Cheungpasitporn, W.; Cheng, Z.; Qian, Q. Chloride alterations in hospitalized patients: Prevalence and outcome significance. PLOS ONE 2017, 12, e0174430. [CrossRef]

52. Huang, K.; Hu, Y.; Wu, Y.; Ji, Z.; Wang, S.; Lin, Z.; Pan, S. Hyperchloremia is associated with poorer outcome in critically Ill stroke patients. Front. Neurol. 2018, 9, 485. [CrossRef]

53. Semler, M.W.; Self, W.H.; Wanderer, J.P.; Ehrenfeld, J.M.; Wang, L.; Byrne, D.W.; Stollings, J.L.; Kumar, A.B.; Hughes, C.G.; Hernandez, A.; et al. Balanced crystalloids versus saline in critically Ill adults. N. Engl. J. Med. 2018, 378, 829-839. [CrossRef]

54. Krajewski, M.L.; Raghunathan, K.; Paluszkiewicz, S.M.; Schermer, C.R.; Shaw, A.D. Meta-analysis of high-versus low-chloride content in perioperative and critical care fluid resuscitation. Br. J. Surg. 2015, 102, 24-36. [CrossRef]

55. Laffey, J.G.; Kavanagh, B.P. Hypocapnia. N. Engl. J. Med. 2002, 347, 43-53. [CrossRef]

56. Rudolf, M.; Riordan, J.F.; Grant, B.J.; Maberly, D.J.; Saunders, K.B. Arterial blood gas tensions in acute severe asthma. Eur. J. Clin. Investig. 1980, 10, 55-62. [CrossRef]

57. Buda, A.J.; Pinsky, M.R.; Ingels, N.B., Jr.; Daughters, G.T., 2nd; Stinson, E.B.; Alderman, E.L. Effect of intrathoracic pressure on left ventricular performance. N. Engl. J. Med. 1979, 301, 453-459. [CrossRef]

58. Jardin, F.; Farcot, J.C.; Boisante, L.; Prost, J.F.; Gueret, P.; Bourdarias, J.P. Mechanism of paradoxic pulse in bronchial asthma. Circulation 1982, 66, 887-894. [CrossRef]

59. Grassino, A.; Macklem, P.T. Respiratory muscle fatigue and ventilatory failure. Annu. Rev. Med. 1984, 35, 625-647. [CrossRef]

60. Freedman, S.; Cooke, N.T.; Moxham, J. Production of lactic acid by respiratory muscles. Thorax 1983, 38, 50-54. [CrossRef]

61. Brady, H.R.; Ryan, F.; Cunningham, J.; Tormey, W.; Ryan, M.P.; O’Neill, S. Hypophosphatemia complicating bronchodilator therapy for acute severe asthma. Arch. Intern. Med. 1989, 149, 2367-2368. [CrossRef]

62. Pesta, D.H.; Tsirigotis, D.N.; Befroy, D.E.; Caballero, D.; Jurczak, M.J.; Rahimi, Y.; Cline, G.W.; Dufour, S.; Birkenfeld, A.L.; Rothman, D.L.; et al. Hypophosphatemia promotes lower rates of muscle ATP synthesis. FASEB J. 2016, 30, 3378-3387. [CrossRef] [PubMed]

63. Aubier, M.; Murciano, D.; Lecocguic, Y.; Viires, N.; Jacquens, Y.; Squara, P.; Pariente, R. Effect of hypophosphatemia on diaphragmatic contractility in patients with acute respiratory failure. N. Engl. J. Med. 1985, 313, 420-424. [CrossRef] [PubMed]

64. Sheldon, G.F. Hyperphosphatemia, hypophosphatemia, and the oxy-hemoglobin dissociation curve. J. Surg. Res. 1973, 14, 367-372. [CrossRef] 
65. Henrion, J.; Minette, P.; Colin, L.; Schapira, M.; Delannoy, A.; Heller, F.R. Hypoxic hepatitis caused by acute exacerbation of chronic respiratory failure: A case-controlled, hemodynamic study of 17 consecutive cases. Hepatology 1999, 29, 427-433. [CrossRef] [PubMed]

66. Ford, R.M.; Book, W.; Spivey, J.R. Liver disease related to the heart. Transplant. Rev. (Orlando) 2015, $29,33-37$. [CrossRef]

67. Waseem, N.; Chen, P.H. Hypoxic hepatitis: A review and clinical update. J. Clin. Transl. Hepatol. 2016, 4, 263-268. [PubMed]

68. Sterling, S.A.; Puskarich, M.A.; Jones, A.E. The effect of liver disease on lactate normalization in severe sepsis and septic shock: A cohort study. Clin. Exp. Emerg. Med. 2015, 2, 197-202. [CrossRef]

69. De Jonghe, B.; Cheval, C.; Misset, B.; Timsit, J.F.; Garrouste, M.; Montuclard, L.; Carlet, J. Relationship between blood lactate and early hepatic dysfunction in acute circulatory failure. J. Crit. Care 1999, 14, 7-11. [CrossRef]

70. Gillani, S.; Cao, J.; Suzuki, T.; Hak, D.J. The effect of ischemia reperfusion injury on skeletal muscle. Injury 2012, 43, 670-675. [CrossRef]

71. Kalogeris, T.; Baines, C.P.; Krenz, M.; Korthuis, R.J. Ischemia/Reperfusion. Compr. Physiol. 2016, 7, $113-170$.

72. Ind, P.W.; Causon, R.C.; Brown, M.J.; Barnes, P.J. Circulating catecholamines in acute asthma. Br. Med. J. (Clin. Res. Ed.) 1985, 290, 267-269. [CrossRef]

73. Papiris, S.A.; Manali, E.D.; Kolilekas, L.; Triantafillidou, C.; Tsangaris, I. Acute severe asthma: New approaches to assessment and treatment. Drugs 2009, 69, 2363-2391. [CrossRef]

74. Stratakos, G.; Kalomenidis, J.; Routsi, C.; Papiris, S.; Roussos, C. Transient lactic acidosis as a side effect of inhaled salbutamol. Chest 2002, 122, 385-386. [CrossRef]

75. Barth, E.; Albuszies, G.; Baumgart, K.; Matejovic, M.; Wachter, U.; Vogt, J.; Radermacher, P.; Calzia, E. Glucose metabolism and catecholamines. Crit. Care Med. 2007, 35, S508-S518. [CrossRef] [PubMed]

76. Reverte, M.; Moratinos, J. Effects of salbutamol and BRL 37344 on diastolic arterial blood pressure, plasma glucose and plasma lactate in rabbits. Fundam. Clin. Pharmacol. 1994, 8, 417-424. [CrossRef]

77. Haffner, C.A.; Kendall, M.J. Metabolic effects of beta 2-agonists. J. Clin. Pharm. Ther. 1992, 17, $155-164$. [CrossRef]

78. Batenburg, J.J.; Olson, M.S. Regulation of pyruvate dehydrogenase by fatty acid in isolated rat liver mitochondria. J. Biol. Chem. 1976, 251, 1364-1370. [PubMed]

79. Kovacevic, A.; Schwahn, B.; Schuster, A. Hyperlactic acidosis as metabolic side-effect of albuterol and theophylline in acute severe asthma. Klin. Padiatr. 2010, 222, 271-272. [CrossRef] [PubMed]

80. Barnes, P.J. Theophylline. Am. J. Respir. Crit. Care Med. 2013, 188, 901-906. [CrossRef] [PubMed]

81. Sturney, S.; Suntharalingam, J. Treating acute asthma-salbutamol may not always be the right answer. Clin. Med. (Lond.) 2012, 12, 181-182. [CrossRef]

82. Stiles, G.L.; Caron, M.G.; Lefkowitz, R.J. Beta-adrenergic receptors: Biochemical mechanisms of physiological regulation. Physiol. Rev. 1984, 64, 661-743. [CrossRef] [PubMed]

83. Dodda, V.R.; Spiro, P. Can albuterol be blamed for lactic acidosis? Respir. Care 2012, 57, 2115-2118. [CrossRef] [PubMed]

84. Vernon, C.; Letourneau, J.L. Lactic acidosis: Recognition, kinetics, and associated prognosis. Crit. Care Clin. 2010, 26, 55-83. [CrossRef] [PubMed]

85. Gutierrez, G.; Wulf, M.E. Lactic acidosis in sepsis: A commentary. Intensive Care Med. 1996, $22,6-16$. [CrossRef] [PubMed]

(C) 2019 by the authors. Licensee MDPI, Basel, Switzerland. This article is an open access article distributed under the terms and conditions of the Creative Commons Attribution (CC BY) license (http://creativecommons.org/licenses/by/4.0/). 